\title{
HUBUNGAN LAMA HARI RAWAT DENGAN TANDA DAN GEJALA SERTA KEMAMPUAN PASIEN DALAM MENGONTROL HALUSINASI
}

\author{
Retno Utami ${ }^{1}$, Prastiwi Puji Rahayu ${ }^{2}$ \\ ${ }^{1}$ Program Studi Ilmu Keperawatan, Universitas ‘Aisyiyah Yogyakarta \\ RSJ Grhasia Yogyakarta \\ retnou1996@gmail.com
}

\begin{abstract}
ABSTRAK
Dampak adanya halusinasi dapat mengakibatkan seseorang mengalami ketidakmampuan untuk berkomunikasi atau mengenali realitas yang menimbulkan kesukaran dalam kemampuan seseorang untuk berperan sebagaimana mestinya dalam kehidupan sehari-hari. Dampak bagi keluarga halusinasi sulit diterima oleh masyarakat, individu dan dipandang negatif oleh lingkungan.Mengetahui hubungan lama hari rawat dengan tanda dan gejala serta kemampuan pasien dalam mengontrol halusinasi di RSJ Grhasia Yogyakarta. Penelitian ini menggunakan menggunakan Desain penelitian studi korelasional (Corrrelation study). Penelitian ini menggunakan teknik total sampling, Sampel yang digunakan dalam penelitian ini berjumlah 45 pasien halusinasi yang ada diruang inap Rumah Sakit Jiwa Grhasia Yogyakarta. Metode analisis yang digunakan adalah uji statistik menggunakan kendal Tau. Hasil penelitian ini menunjukkan bahwa berdasarkan lama hari rawat pasien halusinasi Di RSJ Grhasia Yogyakarta didapatkan paling banyak lebih dari 30 hari sebanyak 42 responden, tanda dan gejala pasien halusinasi Di RSJ Grhasia Yogyakarta didapatkan paling banyak kategori kurang sebanyak 30 responden, dan kemampuan pasien dalam mengontrol halusinasi Di RSJ Grhasia Yogyakarta didapatkan paling banyak kategori cukup sebanyak 27 responden.Tidak ada hubungan lama hari rawat dengan tanda dan gejala dilihat dari nilai $p$-value sebesar $0,170<0,05$, dan terdapat hubungan lama hari rawat dengan kontrol halusinasi dilihat dari nilai $p$-value sebesar $0,030<0,05$ dengan nilai keeratan hubungan 0,325 dalam kategori rendah. Bagi pimpinan RS agar memberikan pengembangan pelayanan kesehatan pada pasien dalam meningkatkan kualitas pelayanan, khususnya dalam lama hari rawat dengan tanda dan gejala kemampuan pasien dalam mengontrol halusinasi. Alahkah baiknya ada perbandingan antara tanda dan gejala sebelum di teliti dan sesudah di teliti.
\end{abstract}

Kata kunci: Lama hari rawat, tanda dan gejala, kemampuan mengontrol halusinasi

\section{THE CORRELATION BETWEEN INPATIENT DURATION, AND SIGNS, SYMPTHOMS AND PATIENT'S ABILITY TO CONTROL HALLUCINATIONS}

\begin{abstract}
Hallucinations can cause disability to communicate or recognize the reality that creates difficulties to act properly in everyday life. The impact of hallucinations on the family is hard to accept by society and individuals, and it is viewed as negative thing by the environment. The study aims to identify the correlation between inpatient duration and signs, symptoms and patient's ability to control the hallucinations at Grhasia Mental Hospital of Yogyakarta. This study used correlational study design. This study used total sampling technique. The samples were 45 hallucination patients at impatient wards at Grhasia Mental Hospital of Yogyakarta. The analytical method used statistical test using Tau constraints. The results of this study indicated that based on the hallucination of inpatient duration at Grhasia Mental Hospital of Yogyakarta, there were 42 respondents who had 30 days of inpatient duration; there were 30 respondents of hallucination patients at Grhasia Mental Hospital of Yogyakarta who have signs and symptoms in low category; there were 27 respondents at Grhasia Mental Hospital of Yogyakarta who had the ability in controlling hallucinations in moderate category. There was not any correlation between inpatient duration and signs and symptoms that can be seen from the p-value of $0.170<0.05$, and there was correlation between the inpatient duration and the control of hallucinations that can be seen from the p-value of $0.030<0.05$ with the closeness value 0.325 in low category. Hospital boards are suggested to provide the development of health services to patients in improving the quality of care, especially about inpatient duration and signs and symptoms
\end{abstract}


of the patient's ability to control hallucinations. Is it better to have a comparison between the signs and symptoms before and after being studied.

\section{Keywords: Inpatient Duration, signs and symptoms, ability to control hallucinations}

\section{PENDAHULUAN}

Skizofrenia adalah Gangguan jiwa berat (psikosis) yang bersifat kronis atau kambuh ditandai dengan terdapatnya pepecahan (schism) anatara pikiran, emosi dan perilaku pasien yang terkena. Pepecahan pada pasien digambarkan dengan adanya gejala fundamental (atau primer ) spesifik, yaitu gangguan asosiasi, khususnya kelonggaran asosiasi. Gejala fundamental lainya adalah gangguan afektif, autisme, dan ambivalensi. Sedangkan gejala sekundernya adalah waham dan halusinasi (Stuart, 2013).

Kebijakan pemerintah dalam menangani gangguan kesehatan jiwa tercantum dalam Undang-Undang Nomer 36 tahun 2009 tentang kesehatan jiwa Bab IX Kesehatan Jiwa pasal 148 (1) penderita gangguan jiwa mempunyai hak yang sama sebagai warga negara. (2) Hak sebagaimana dimaksud pada ayat tersebut meliputi persamaan perlakuan dalam setiap aspek kehidupan kecuali peraturan perundangundangan menyatakan lain. Selain itu, upaya kesehatan jiwa juga harus dilakukan secara komperehensif (promotif, preventif, kuratif, rehabilitatif) dan pelayanan ditunjukan kepada individu, masyarakat serta keluarga.

World Health Organization (WHO, 2010) memperkirakan bahwa 151 juta orang menderita gangguan jiwa dan 26 juta orang menderita skizofrenia. Menurut (National Institute of Mental Health) (NIMH) berdasarkan hasil sensus penduduk Amerika Serikat tahun 2004, diperkirakan 26,2\% penduduk yang berusia 18 tahun lebih mengalami gangguan jiwa (NIMH, 2011).

Halusinasi merupakan salah satu gejala yang sering ditemukan pada pasien dengan gangguan jiwa, halusinasi sering diidentikan dengan skizofrenia. Dari seluruh pasien skizofrenia 70 $\%$ diantaranya mengalami halusinasi. Gangguan jiwa yang lain juga disertai dengan halusinasi adalah gangguan manik depresif dan delerium. (Praptoharsoyo, 2012). Tanda dan gejala halusinasi ada kognitif, afektif, fisiologis, perilaku, sosial.
Menurut Depkes RI, 2009 mencatat Masalah gangguan jiwa yang sering dialami oleh pasien yaitu halusinasi yang dibuktikan dengan data : Halusinasi (41\%), Kekerasan (39,2\%), Depresi (16,9\%), Isolasi sosial (11,7\%), Waham $(2,8 \%)$, Harga diri rendah $(2,1 \%)$, Bunuh diri $(2,3 \%)$. Berdasarkan data Riset Kesehatan Republik Dasar (Riskesdes) tahun 2013 menunjukan bahwa prevalensi gangguan jiwa 1-2 orang per 1.000 penduduk. Diperkiran sekitar 400 ribu orang yang mengalami halusinasi. Dari jumlah tersebut sekitar 75.000 orang yang pernah atau sedang di pasung. Sekitar $80 \%$ pasien di rawat di RSJ dengan gangguan halusinasi yaitu $25 \%$ pasien halusinasi dapat sembuh, $25 \%$ dapat mandiri, $25 \%$ membutuhkan bantuan, dan $25 \%$ kondisi berat.

Dampak adanya halusinasi dapat mengakibatkan seseorang mengalami ketidakmampuan untuk berkomunikasi atau mengenali realitas yang menimbulkan kesukaran dalam kemampuan seseorang untuk berperan sebagaimana mestinya dalam kehidupan sehari-hari. Banyak hal yang dapat berdampak dari perilaku kekanak-kanakan, waham dan halusinasi yang diperlihatkan oleh individu dengan skizofrenia halusinasi.

Dampak lain bagi keluarga diakibatkan gangguan jiwa halusinasi sulit diterima dalam masyarakat dikarenakan perilaku individu tidak sesuai dengan nilai dan norma yang berlaku, individu akan dipandang negatif oleh lingkungan, dikarenakan lingkungan masih belum terbiasa oleh kondisi yang terjadi pada individu yang mengalami gangguan jiwa halusinasi, yang pada akhirnya kebanyakan keluarga tertentu membuat keputusan untuk mengurung individu dalam sebuah kerangkeng (dipasung) dengan tujuan agar tidak diketahui oleh masyarakat, tidak melakukan kekerasan/kerusakan sehingga keluarga terhindar dari rasa malu (Maramis, 2004 dalam Irmasyah, 2010).

Kekambuhan halusinasi merupakan peristiwa timbulnya kembali gejala-gejala gangguan psikis atau jiwa yang sebelumnya susah 
memperoleh kemajuan. Pada gangguan jiwa kronis, diperkirakan $50 \%$ penderita gangguan jiwa kronis akan mengalami kekambuhan pada tahun pertama, dan $70 \%$ pada tahun kedua. Kekambuhan biasanya terjadi karena hal-hal buruk yang menimpa penderita gangguan jiwa, seperti diasingkan oleh keluarganya sendiri (Wiramisharjo, 2007).

Lama hari rawat merupakan salah satu unsur atau aspek asuhan dan pelayanan dirumah sakit yang dapat dinilai dan diukur. Lama hari rawat dapat diukur dengan cara mengukur dengan jangka panjang dan jangka pendek. Jangka pendek akan memberi keuntungan penghematan biaya dan sumber yang lebih sedikit terhadap rumah sakit terutama bagi pasien itu sendiri. Sedangkan jangka panjang banyak pembiayaan perawatan pasien yang harus ditanggung oleh rumah sakit atau keluarga. Lama hari rawat dapat digunakan untuk melihat seberapa efektif dan efisiennya pelayanan kesehatan jiwa yang telah diberikan, dapat diukur dengan berapa lama hari perawatan dan kemampuan pasien setelah mendapatkan terapi pengobatan dirumah sakit tersebut (Husain, 2008). Danardi (2007) menyatakan bahwa kualitas pelayanan kesehatan sangat mempengaruhi lama hari rawat pasien, semakin baik kualitas pelayanan kesehatan yang diberikan maka semakin cepat masa rawatnya.

Kemampuan dalam mengontrol halusinasi tiap pasien selalu dipengaruhi keadaan individu yang mengalami suatu gangguan dalam aktivitas mental seperti berpikir sadar, orientasi realitas, pemecahan masalah, penilaian dan pemahaman yang berhubungan dengan koping (Stuart, 2007). Dengan gejala tidak akuratnya interpretasi tentang stimulus eksternal dan internal dari tiap individu yang mengalami gangguan jiwa maka kemampuan untuk mengontrol halusinasi juga akan dipengaruhi. Serta kemampuan klien dalam mengontrol halusinasi dapat dipengaruhi oleh berbagai faktor baik ekstemal maupun internal. Salah satu faktor eksternal adalah lama hari rawat. Namun pada kenyataannya masih banyak klien yang belum bisa mengontrol halusinasinya meskipun mendapatkan perawatan yang lama.

Menurut hasil penelitian Noviandi (2008). tentang perubahan kemampuan mengontrol halusinasi terhadap terapi individu diruang Model Praktek Keperawatan Profesional (MPKP), menggambarkan hari 1-12 responden mampu mengenal halusinasi. Hari ke 4-21, responden mampu menggunakan tehnik menghardik untuk mengontrol halusinasi. Hari ke 5-22, responden mampu menggunakan tehnik bercakap-cakap dengan orang Iain untuk mengontrol halusinasi. Hari ke 9-25, responden mampu menggunakan aktitltas teijadwal untuk mengontrol halusinasi. Hari 13-30, responden mampu menggunakan obat secara teratur. Semakin lama klien dirawat maka semakin banyak klien tersebut mendapatkan terapi pengobatan dan perawatan, sehingga klien akan mampu mengontol halusinasinya.

Berdasarkan studi pendahuluan yang sudah dilakukan peneliti di rumah sakit jiwa grhasia yogyakarta pada tanggal 02 Januari 2018 didapatkan data bahwa penyakit di rumah sakit jiwa grhasia. Jumlah kasus 10 besar penyakit dirumah sakit jiwa grhasia berjumlah 671 kasus dan $(39,1 \%)$ adalah penyakit undifferentiated schizophrenia dari kasus yang ada. Penyakit undifferentiated schizophrenia (F20.3) cukup meningkat dari bulan ke bulan Oktober sampai Desember. Bulan Oktober sampai Desember terdapat 105 pasien undifferentiated schizophrenia. Dari hasil wawancara kepada 6 kepala ruangan dirumah sakit jiwa grhasia diperoleh hasil bahwa rata-rata pasien halusinasi yang dirawat dirumah sakit jiwa grhasia dapat mengontrol halusinasinya di minggu kedua atau (14 hari) perawatan dan 1 kepala ruangan diantaranya menyampaikan bahwa pasien halusinasi yang dirawat dapat mengontrol halusinasi di minggu pertama atau (7 hari). Berdasarkan latar belakang yang telah diuraikan diatas, peneliti tertarik untuk meneliti tentang hubungan lama hari rawat dengan tanda dan gejala, serta kemampuan pasien dalam mengontrol halusinasi di RSJ Grhasia Yogyakarta.

\section{METODE}

Penelitian ini adalah penelitian kuantitatif menggunakan Desain penelitian studi korelasional (Corrrelation study), dengan Pendekatan Cross Sectional. Populasi dalam penelitian ini 45 pasien yang mengalami halusinasi yang ada di Rumah Sakit Jiwa Grahsia Yogyakarta Sampel yang digunakan dalam penelitian ini berjumlah 45 pasien halusinasi yang ada diruang inap Rumah Sakit Jiwa Grhasia Yogyakarta. Cara pengambilan sampel pada penelitian ini adalah Total Sampling. Penelitian ini telah menggunakan alat pengumpulan data berupa kuisoner. Uji statistik yang digunakan dalam penelitian ini adalah korelasi Kendall Tau 
HASIL

berikut.

Hasil penelitian dapat dilihat pada tabel

Tabel 1

Karakteristik responden berdasarkanjenis kelamin, umur, pendidikan, pekerjaan, status perkawinan

\begin{tabular}{|c|c|c|c|}
\hline Karakteristik & Kategori & $\mathrm{f}$ & $\%$ \\
\hline \multirow[t]{2}{*}{ Jenis kelamin } & Laki-laki & 17 & 37,8 \\
\hline & Perempuan & 28 & 62,2 \\
\hline \multirow[t]{4}{*}{ Umur } & 25-30 tahun & 6 & 13,3 \\
\hline & 31-35 tahun & 15 & 33,3 \\
\hline & 36-40 tahun & 12 & 26,7 \\
\hline & 41-45 tahun & 12 & 26,7 \\
\hline \multirow[t]{3}{*}{ Pendidikan } & Smp & 12 & 26,7 \\
\hline & Sma & 25 & 55,6 \\
\hline & Sarjana & 8 & 17,8 \\
\hline \multirow[t]{4}{*}{ Pekerjaan } & Pns & 7 & 15,6 \\
\hline & Karyawan & 16 & 35,6 \\
\hline & Wiraswasta & 12 & 26,7 \\
\hline & Tidak bekerja & 10 & 22,2 \\
\hline \multirow[t]{3}{*}{ Status perkawinan } & Kawin & 33 & 73,3 \\
\hline & Belum kawin & 8 & 17,8 \\
\hline & Janda & 4 & 8,9 \\
\hline \multicolumn{2}{|c|}{$\begin{array}{l}\text { kelamin paling banyak berjenis kelamin } \\
\text { perempuan sebanyak } 28 \text { responden }(62,2 \%) \text {, } \\
\text { berdasarkan usia paling banyak berusia } 31-35 \\
\text { tahun sebanyak } 15 \text { responden }(33,3 \%) \text {, } \\
\text { berdasarkan pendidikan paling banyak }\end{array}$} & \multicolumn{2}{|c|}{$\begin{array}{l}25 \text { responden }(55,6 \%) \text {, berdasarkan pekerjaan } \\
\text { paling banyak memiliki pekerjaan sebagai } \\
\text { karyawan sebanyak } 16 \text { responden }(35,6 \%) \text {, } \\
\text { berdasarkan status perkawinan paling banyak } \\
\text { memiliki status perkawinan kawin sebanyak } 33 \\
\text { responden }(73,3 \%) \text {. }\end{array}$} \\
\hline
\end{tabular}

Tabel 2

Lama Hari Rawat Pasien Halusinasi $(n=45)$

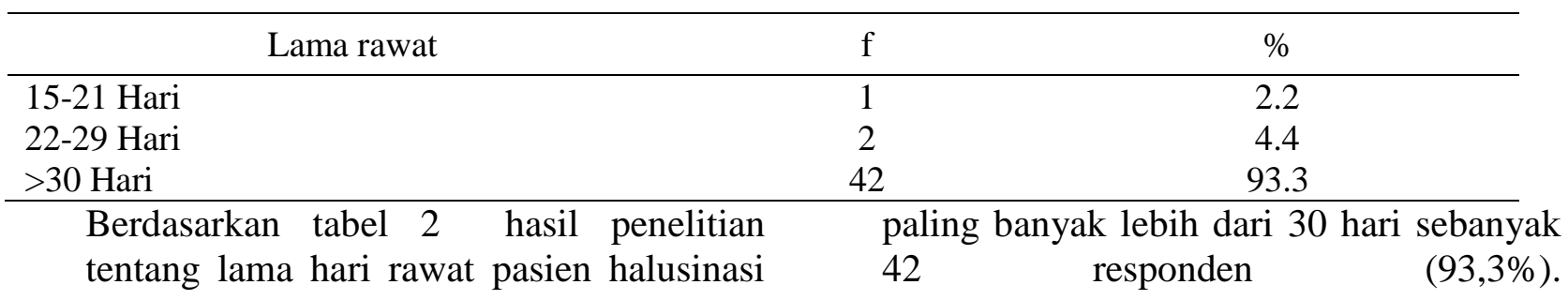

Tabel 3

Tanda dan Gejala Pasien Halusinasi $(\mathrm{n}=45)$

\begin{tabular}{cccc}
\hline Tanda dan Gejala & Tanda dan Gejala & $\mathrm{f}$ & $\%$ \\
\hline Kognitif & Tidak & 14 & $31,1 \%$ \\
& Ya & 31 & $68,9 \%$ \\
Afektif & Tidak & 45 & $100,0 \%$ \\
& Ya & 0 & $0 \%$ \\
Fisiologi & Tidak & 7 & $15,6 \%$ \\
& Ya & 38 & $84,4 \%$ \\
Perilaku & Tidak & 15 & $33,3 \%$ \\
& Ya & 30 & $66,7 \%$ \\
Sosial & Tidak & 13 & $28,9 \%$ \\
& Ya & 32 & $71,1 \%$ \\
\hline
\end{tabular}


Berdasarkan tabel 3 hasil penelitian tentang tanda dan gejala pasien halusinasi paling banyak pada aspek fisiologis sebanyak 38 responden $(84,4 \%)$.

Tabel 4

Kemampuan Pasien Dalam Mengontrol $(n=45)$

\begin{tabular}{ccc}
\hline Kontrol Halusinasi & f & $\%$ \\
\hline Baik & 18 & 40.0 \\
Cukup & 27 & 60.0
\end{tabular}

Sumber : Data primer (2018)

Berdasarkan tabel 4 hasil penelitian tentang kemampuan pasien dalam mengontrol

halusinasi paling banyak kategori cukup sebanyak 27 responden $(60 \%)$.

Tabel 5

Tabulasi Silang Hubungan Lama Hari Rawat Dengan Tanda dan Gejala $(\mathrm{n}=45)$

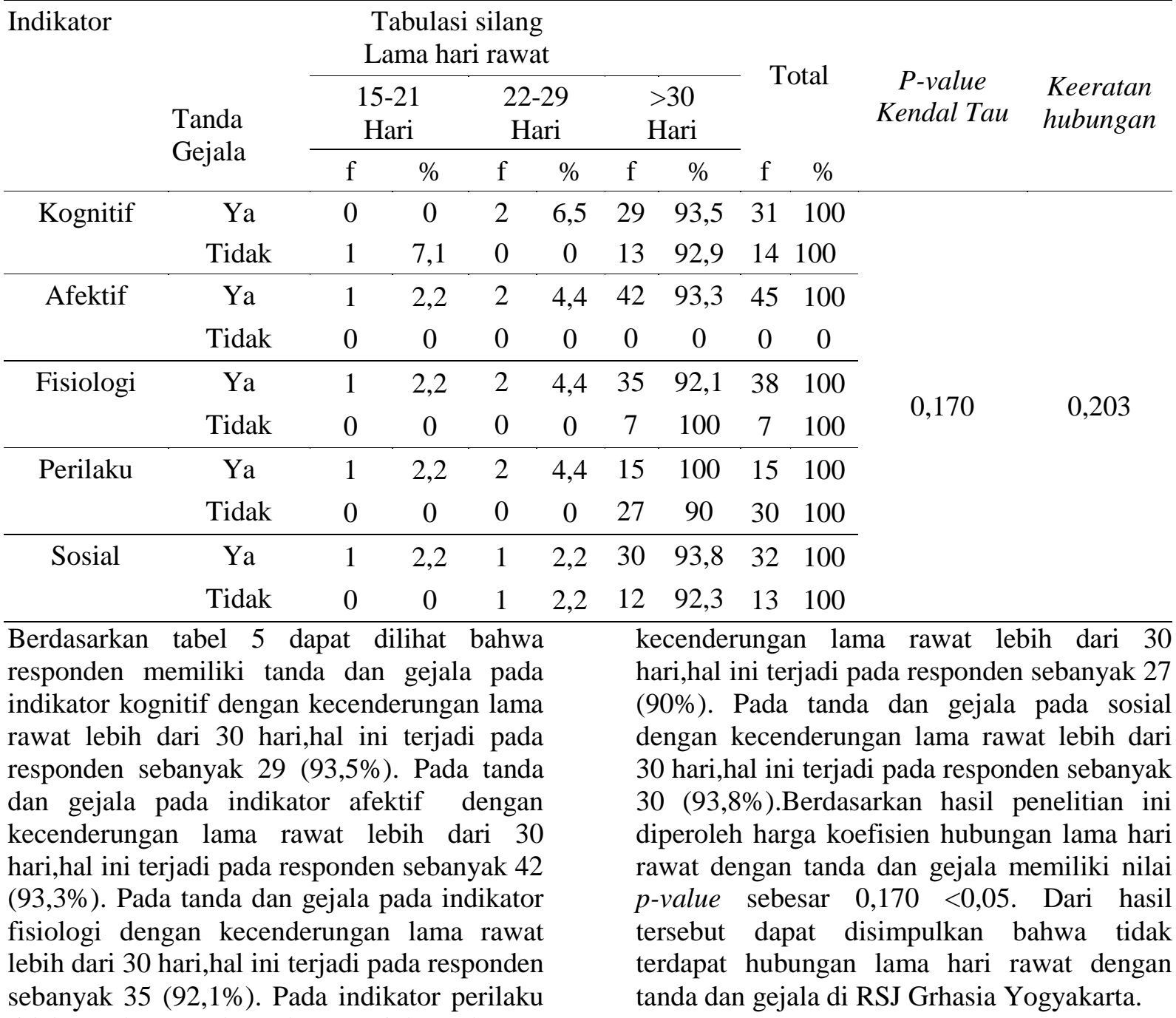


Tabel 6

Tabulasi Silang Hubungan Lama Hari Rawat Dengan kemampuan pasien dalam mengontrol halusinasi $(n=45)$

\begin{tabular}{|c|c|c|c|c|c|c|c|c|c|c|}
\hline \multirow{3}{*}{ Kontrol Halusinasi } & \multicolumn{6}{|c|}{$\begin{array}{l}\text { Tabulasi silang } \\
\text { Lama hari rawat }\end{array}$} & \multirow{2}{*}{\multicolumn{2}{|c|}{ Total }} & \multirow{3}{*}{$\begin{array}{c}P \text {-value } \\
\text { Kendal } \\
\text { Tau }\end{array}$} & \multirow{3}{*}{$\begin{array}{l}\text { Keeratan } \\
\text { hubungan }\end{array}$} \\
\hline & \multicolumn{2}{|c|}{$\begin{array}{c}15-21 \\
\text { Hari }\end{array}$} & \multicolumn{2}{|l|}{$\begin{array}{c}22-29 \\
\text { Hari }\end{array}$} & \multicolumn{2}{|c|}{$\begin{array}{l}>30 \\
\text { Hari }\end{array}$} & & & & \\
\hline & $\mathrm{f}$ & $\%$ & $\mathrm{f}$ & $\%$ & $\mathrm{f}$ & $\%$ & $\mathrm{f}$ & $\%$ & & \\
\hline Baik & 1 & 2,2 & 2 & 4,4 & 25 & 33,3 & 18 & 40 & 0,030 & 0,325 \\
\hline Cukup & 0 & 0 & 0 & 0 & 27 & 60 & 27 & 60 & & \\
\hline Kurang & 0 & 0 & 0 & 0 & 0 & 0 & 0 & 0 & & \\
\hline
\end{tabular}

Berdasarkan tabel 6 dapat dilihat bahwa paling banyak responden memiliki kontrol halusinasi kategori cukup dengan bantuan tenaga medis dengan kemampuan tindakan keperawatan generalis memiliki kecenderungan lama rawat lebih dari 30 Hari berjumlah $27(60 \%)$ responden. Sedangkan responden yang memiliki kontrol halusinasi kategori baik tanpa bantuan tenaga medis dengan kemampuan mengenal halusinasi memiliki kecenderungan lama hari rawat lebih dari 30 hari berjumlah $25(33,3 \%)$ responden. Berdasarkan hasil penelitian ini diperoleh harga koefisien hubungan lama hari rawat dengan kontrol halusinasi memiliki nilai $p$ value sebesar $0,030<0,05$. Dari hasil tersebut dapat disimpulkan bahwa terdapat hubungan lama hari rawat dengan kontrol halusinasi di RSJ Grhasia Yogyakarta memiliki keeratan hubungan sebesar 0,325 yang artinya memiliki keeratan hubungan rendah.

\section{PEMBAHASAN}

\section{Lama Hari Rawat Pasien Halusinasi}

Hasil penelitian tentang lama hari rawat pasien halusinasi didapatkan paling banyak lebih dari 30 hari sebanyak 42 responden $(93,3 \%)$. Lama hari rawat adalah menunjukkan berapa hari lamanya seorang pasien dirawat inap pada satu periode perawatan. Dalam penelitian ini didapatkan lama hari rawat responden yaitu lebih dari 30 hari. Penelitian ini berarti menemukan bahwa diagnosa pasien kebanyakan membutuhkan waktu yang lama, sehingga membutuhkan lama hari rawat yang cukup panjang. Lama hari rawat merupakan salah satu unsur atau aspek asuhan dan pelayanan di rumah sakit yang dapat dinilai atau diukur. Bila seseorang dirawat di rumah sakit, maka yang diharapkan tentunya ada perubahan akan derajat kesehatannya. Bila yang diharapkan baik oleh tenaga medis maupun oleh penderita itu sudah tercapai maka tentunya tidak ada seorang pun yang ingin berlama-lama di rumah sakit. Lama hari rawat secara signifikan berkurang sejak adanya pengetahuan tentang hal-hal yang berkaitan dengan diagnosa yang tepat.

Hasil penelitian ini sesuai dengan teori Barbara (2008: dalam Krzysztof, 2011) yang menyatakan bahwa faktor yang mempengarui lama hari rawat salah satunya jenis kasus atau penyakit. Kasus yang akut dan kronis akan memerlukan lama hari rawat yang berbeda, dimana kasus yang kronis akan memerlukan lama hari rawat lebih lama dari pada kasuskasus yang bersifat akut. Demikian juga penyakit yang tunggal pada satu penderita akan mempunyai lama hari rawat lebih pendek dari pada penyakit ganda pada satu penderita .

Hasil uraian penelitian ini juga sesuai dengan teori Husain (2008) yang menyatakan Lama hari rawat dapat digunakan untuk melihat seberapa efektif dan efisiennya pelayanan kesehatan jiwa yang telah diberikan, dapat diukur dengan berapa lama hari perawatan dan kemampuan pasien setelah mendapatkan terapi pengobatan dirumah sakit tersebut (Husain, 2008).

\section{Tanda dan Gejala Pasien Halusinasi}

Hasil penelitian tentang tanda dan gejala pasien halusinasi didapatkan memiliki tanda dan gejala pada indikator kognitif dengan kecenderungan lama rawat lebih dari 30 hari,hal ini terjadi pada responden sebanyak 29 $(93,5 \%)$. Pada tanda dan gejala pada indikator afektif dengan kecenderungan lama rawat lebih dari 30 hari,hal ini terjadi pada responden sebanyak $42(93,3 \%)$.

Pada tanda dan gejala pada indikator fisiologi dengan kecenderungan lama rawat lebih dari 30 hari,hal ini terjadi pada responden sebanyak 
35 (92,1\%). Pada indikator perilaku tidak ada tanda dan gejala dengan kecenderungan lama rawat lebih dari 30 hari,hal ini terjadi pada responden sebanyak 27 (90\%). Pada tanda dan gejala pada sosial dengan kecenderungan lama rawat lebih dari 30 hari,hal ini terjadi pada responden sebanyak $30(93,8 \%)$.

Halusinasi adalah persepsi salah satu gangguan jiwa pada individu yang ditandai dengan perubahan persepsi sensori seseorang yang hanya mengalami rangsang internal (pikiran) tanpa disertai adanya rangsang eksternal (dunia luar) yang sesuai. Halusinasi terjadi karena klien tersebut pada dasarnya memiliki koping yang tidak efektif terhaap berbagai stresor yang menimpanya. Kondisi yang timbul karena kondisi di atas adalah klien cenderung akan menarik diri dari lingkungan dan terjadilah isolasi sosial. Kesendirian tersebut jika berlangsung lama akan menimbulkan halusinasi dan semakin lama klien akan semakin menikmati dan asik dengan halusinasinya itu. Karena adanya hal yang tidak nyata akan muncul perintah yang bisa menyuruh klien merusak diri sendiri dan lingkungan di sekitarnya (Keliat dkk, 2009).

Gejala halusinasi tidak langsung ditangani, penanganan yang lama mengakibatkan diagnosa penyakit juga lama. Hal ini akan mempengaruhi lama hari rawat pasien. sehingga mayoritas responden memiliki lama rawat lebih dari 30 hari. Hal ini sesuai dengan teori Stuart (2007) bahwa dengan gejala tidak akuratnya interpretasi tentang stimulus eksternal dan internal dari tiap individu yang mengalami gangguan jiwa maka kemampuan untuk mengontrol halusinasi juga akan dipengaruhi.

\section{Kemampuan Pasien Dalam Mengontrol Halusinasi}

Hasil penelitian tentang kemampuan pasien dalam mengontrol halusinasi didapatkan paling banyak kategori cukup sebanyak 27 responden (60\%). Dalam penelitian ini didapatkan bahwa pasien memiliki kontrol halusinasi yang cukup, artinya perasaan cemas yang dimiliki pasien dapat dikendalikan sebagian oleh responden seperti perintah memaksa untuk berbuat sesuatu dan juga rasa ketakutan. Dalam hal ini dukungan keluarga sangat dibutuhkan agar pasien tidak menyendiri, jika pasien menyendiri akan menyebabkan kambuhnya halusinasi pasien. kemampuan klien dalam mengontrol halusinasi dapat dipengaruhi oleh berbagai faktor baik ekstemal maupun internal. Salah satu faktor eksternal adalah lama hari rawat. Namun pada kenyataannya masih banyak klien yang belum bisa mengontrol halusinasinya meskipun mendapatkan perawatan yang lama. Apabila pasien dibiarkan saja maka akan terjadi halusinasi yang akan mengakibatkan ketidakharmonisan berinteraksi. Penurunan kemampuan untuk menghadapi stress dan kecemasan serta menurunnya kualitas untuk menilai keadaan sekitarnya. Akibat saat halusinasi menguasai dirinya, klien akan kehilangan kontrol terhadap kehidupanya. Hal ini dikuatkan teori Kemampuan pasien dalam mengontrol halusinasi dapat dipengaruhi oleh beberapa faktor antara lain : Faktor individu atau keinginan untuk sembuh dari penyakit tersebut, Dukungan dari keluarga, Lingkungan sekitar pasien, Terapi yang diberikan oleh petugas kesehatan. Hal ini juga dikuatkan dalam penelitian aktor-faktor yang dapat mempengaruhi kemampuan klien dalam mengontrol halusinasi adalah sikap respon klien terhadap halusinasi. kejujuran memberikan informasi. kepribadian klien. pengalaman dan kemampuan mengingat (Noviandi, 2008)

Menurut teori Maramis (2004 dalam Irmasyah, 2010) Dampak adanya halusinasi dapat mengakibatkan seseorang mengalami ketidakmampuan untuk berkomunikasi atau mengenali realitas yang menimbulkan kesukaran dalam kemampuan seseorang untuk berperan sebagaimana mestinya dalam kehidupan sehari-hari. Banyak hal yang dapat berdampak dari perilaku kekanak-kanakan, waham dan halusinasi yang diperlihatkan oleh individu dengan skizofrenia halusinasi.

Menurut penelitian Reliani (2015) dalam artikel yang berjudul Pelaksanaan Teknik Mengontrol Halusinasi: Kemampuan Klien Skizofrenia Mengontrol Halusinasi menyatakan bahwa Peningkatan kemampuan mengontrol halusinasi pada pasien dipengaruhi oleh adanya pengetahuan pasien cara mengontrol halusinasi, mengenal jenis halusinasi, mengenal isi halusinasi, dan frekuensi terjadinya halusinasi, membuat pasien lebih kuat menghadapi halusinasi. Dari intervensi pelaksanan mengontrol halusinasi yang diberikan mulai itu juga pasien lebih mempunyai mekanisme koping kuat, dengan menerapkan pelaksanaan mengontrol halusinasi terutama dalam SP2 dan SP3 
mengajarkan pada klien untuk selalu beraktifitas dan bersosial, minimal dengan keluarga, yaitu melakukan aktifitas terjadwal dan bercakap-cakap dengan orang lain. Menurut pengamatan pada saat penelitian, pasien yang teratur dan patuh dalam minum obat, lebih cenderung mengurangi kekambuhan. Kepatuhan pasien halusinasi untuk meminum tersebut yang seharusnya menjadikan pekerjaan rumah tersendiri untuk pelayan Kesehatan, bagaimana cara yang paling tepat memanfaatkan pendamping minum obat yang bisa selalu mendampingi pasien. Ada Beberapa pasien dan keluarga yang sering berusaha melepaskan obatnya sendiri tanpa saran dari psikiaternya. Alasan itu karena ketakutan akan ketergantungan. Kejadian ini sering menimbulkan kekambuhan oleh karena itu pasien jiwa dengan halusinasi wajib menerapkan strategi pelaksanaan mengontrol halusinasi dimana pun berada.

\section{Hubungan Lama Hari Rawat Dengan Tanda Dan Gejala Halusinasi}

Hasil penelitian menyatakan paling banyak responden memiliki tanda dan gejala kategori kurang memiliki kecenderungan lama rawat lebih dari 30 Hari berjumlah $30 \quad(66,7 \%)$ responden. Berdasarkan hasil penelitian ini diperoleh harga koefisien hubungan lama hari rawat dengan tanda dan gejala memiliki nilai $p$-value sebesar $0,170>0,05$. Dari hasil tersebut dapat disimpulkan bahwa tidak terdapat hubungan lama hari rawat dengan tanda dan gejala di RSJ Grhasia Yogyakarta. Untuk sifat hubunganya bersifat positif.

Tanda dan gejala yang ditemukan peneliti jika tidak langsung ditangani, penanganan yang lama mengakibatkan diagnosa penyakit juga lama. Hal ini akan mempengaruhi lama hari rawat pasien. sehingga mayoritas responden memiliki lama rawat lebih dari 30 hari. Hasil penelitian ini sesuai dengan teori Stuart (2007) bahwa dengan gejala tidak akuratnya interpretasi tentang stimulus eksternal dan internal dari tiap individu yang mengalami gangguan jiwa maka kemampuan untuk mengontrol halusinasi juga akan dipengaruhi sehingga mengakibatkan lama hari rawat agar pulih kembali.

Lama hari rawat secara signifikan berkurang sejak adanya pengetahuan tentang hal-hal yang berkaitan dengan diagnosa yang tepat. Diagnosa tersebut didapatkan dari melihat tanda dan gejala yang muncul, dengan adanya tanda dan gejala yang muncul akan dapat menyimpulkan jenis kasus atau penyakit tersebut. Hasil penelitian secara rinci dapat dilihat pada hasil kuisoner. Pada tanda dan gejala dalam indikator kognitif didapatkan tanda dan gejala paling banyak dialami responden seperti mendengar suara-suara, melihat bayangan, tidak dapat memfokuskan pikiran, tidak dapat berfikir logis, konsentrasi rendah dan tidak mampu mengambil keputusan.

Tanda dan gejala pada indikator Afektif paling banyak dialami responden seperti senang dengan halusinasinya, merasa terganggu, ketakutan, khawatir dan curiga. Pada indikator fisiologis paling banyak dialami responden seperti kewaspadaan, tekanan darah dan keringat dingin meningkat. Pada tanda dan gejala pada indikator perilaku paling banyak dialami responden seperti menggerakan bibirnya / komat-kamit, cenderung mengikuti halusinasinya dari pada menolak, daya tilik diri kurang, penampilan tidak sesuai, dan menunjukan-nunjuk kearah tertentu. Tanda dan gejala pada indikator sosial paling banyak dialami responden seperti Acuh dengan lingkungan, Kesulitan menjalin hubungan dengan orang lain, dan Tidak tertarik dengan kegiatan harian.

Hasil penelitian ini sesuai dengan teori Barbara J., (2008: dalam Krzysztof, 2011) yang menyatakan bahwa faktor yang mempengarui lama hari rawat salah satunya jenis kasus atau penyakit. Kasus yang akut dan kronis akan memerlukan lama hari rawat yang berbeda, dimana kasus yang kronis akan memerlukan lama hari rawat lebih lama dari pada kasuskasus yang bersifat akut. Demikian juga penyakit yang tunggal pada satu penderita akan mempunyai lama hari rawat lebih pendek dari pada penyakit ganda pada satu penderita . Penyakit tersebut pasti membawa tanda dan gejala yang muncul,

\section{Hubungan Lama Hari Rawat Dengan Kemampuan Pasien Dalam Mengontrol Halusinasi}

Hasil penelitian menyatakan paling banyak responden memiliki kontrol halusinasi kategori cukup memiliki kecenderungan lama rawat lebih dari 30 Hari berjumlah 27 (60\%) responden. Berdasarkan hasil penelitian ini diperoleh harga koefisien hubungan lama hari rawat dengan kontrol halusinasi memiliki nilai 
$p$-value sebesar $0,030<0,05$. Dari hasil tersebut dapat disimpulkan bahwa terdapat hubungan lama hari rawat dengan kontrol halusinasi di RSJ Grhasia Yogyakarta memiliki keeratan hubungan sebesar 0,325 yang artinya memiliki keeratan hubungan rendah.

Kemampuan klien dalam mengontrol halusinasi dapat dipengaruhi oleh berbagai faktor baik ekstemal maupun internal. Salah satu faktor eksternal adalah lama hari rawat. Namun pada kenyataannya masih banyak klien yang belum bisa mengontrol halusinasinya meskipun mendapatkan perawatan yang lama. Menurut teori Kusumawati (2010) Apabila hal tersebut berkelanjutan, seseorang akan menjadi terbiasa dikendalikan halusinasinya dan tidak mampu mematuhi perintah, bahkan dalam fase yang lebih buruk, orang yang mengalami halusinasi dapat berpotensi menjadi perilaku kekerasan bahkan bunih diri, maka diperlukan pengobatan terapi untuk menurunkan halusinasi.

Hasil penelitian ini sesuai teori menurut Husain (2008) bahwa Lama hari rawat dapat digunakan untuk melihat seberapa efektif dan efisiennya pelayanan kesehatan jiwa yang telah diberikan, dapat diukur dengan berapa lama hari perawatan dan kemampuan pasien setelah mendapatkan terapi pengobatan dirumah sakit tersebut. Ditambahkan dalam teori Stuart (2008) yang menyatakan Kemampuan dalam mengontrol halusinasi tiap pasien selalu dipengaruhi keadaan individu yang mengalami suatu gangguan dalam aktivitas mental seperti berpikir sadar, orientasi realitas, pemecahan masalah, penilaian dan pemahaman yang berhubungan dengan koping. kemampuan mengontrol halusinasi memerlukan latihan dan teknik agar dapat tercapai, hal itu akan mempengaruhi masa lama rawat pasien.

Hasil penelitian ini relevan dengan penelitian Menurut hasil penelitian Noviandi (2008). tentang perubahan kemampuan mengontrol halusinasi terhadap terapi individu diruang Model Praktek Keperawatan Profesional (MPKP), menggambarkan hari 1-12 responden mampu mengenal halusinasi. Hari ke 4-21, responden

\section{SIMPULAN DAN SARAN \\ Simpulan}

Hasil penelitian ini menunjukkan bahwa Tidak ada hubungan lama hari rawat dengan tanda dan gejala dilihat dari nilai $p$-value sebesar $0,170>0,05$, dan terdapat hubungan lama hari rawat dengan kontrol halusinasi dilihat dari nilai $p$-value sebesar $0,030<0,05$ dengan nilai keeratan hubungan 0,325 dalam kategori rendah.

\section{Saran}

Bagi Bagi Instansi pelayanan kesehatan RS Grhasia DIY Diharapkan mampu memberikan pengembangan pelayanan kesehatan pada pasien dalam meningkatkan kualitas pelayanan, khususnya dalam lama hari rawat dengan tanda dan gejala kemampuan pasien dalam mengontrol halusinasi.

\section{DAFTAR PUSTAKA}

Barbara, Kozier (2008). Fundamental of Nursing, Seventh edition, Vol.2, Jalarta : EGC.

Danardi (2007). Asuhan keperawatan bermutu di rumah sakit jiwa. Http.II persi,co.id/pada versi/news/artikel.php. 3. Id

Hawari. (2010). Pendekatan Holistik pada gangguan Jiwa Skizofrenia. Jakarta: Fakultas Kedokteran Universitas Indonesia.

Husain. (2008), Gangguan Kesehatan Jiwa.. Diperoleh tanggal 5 September 2010 dari

http://www.Litbang.depkes..go.id/Publik asi- BPPK/Triwulan 2/gangguan jiwa.htm

Keliat, Budi Anna dkk. (2012). Proses Keperawatan Kesehatan Jiwa Edisi 2. Jakarta : EGC .

Kusumawati, F . \& Hartono, Y. (2010). Buku Ajar Keperawatan Jiwa. Jakarta :Salemba Medika.

Maramis, W. F, (2014). Ilmu Kedokteran Jiwa. Edisi 9. Surabaya : Airlangga Universitas Press

NIMH. (2011). National institute of mental health: USA

Noviandi. (2008). Deskripsi Peruhahan Kemampuan Mengontrol Halusinasi Pada Klien Dengan Terapi Individu di Ruang MPKP RSJ Magelang. Diperoleh 
10 September $2010 \quad$ dari http://www.skripsistikes.wordpress.com.

Praptoharsoyo. (2012). Prinsip Dasar dan Aplikasi Penulisan Laporan Pendahuluan dan Strategi Pelaksanaan Tindakan Keperawatan (LP dan SP) : Untuk 7 Diagnosis Keperawatan Jiwa Berat bagi Program S-1 Keperawatan. Jakarta : Salemba Medika

SIMRS Jiwa Grhasia . (2015). Laporan Data 10 Besar Penyakit Rawat Inap Rumah Sakit Jiwa Grhasia Bulan Januari - Juni 2015. Yogyakarta: Rumah Sakit Jiwa Grhasia.

Stuart. GW (2013). Buku Saku Keperawatan Jiwa. edisi 10. Jakarta : EGC

Y. D. Farida Kusumawati. (2010). Buku Ajar Keperawatan Jiwa. Jakarta : Salemba Medika. 